\title{
ANALISIS FAKTOR-FAKTOR YANG MEMENGARUHI PRODUKSI IKAN BANDENG DI KECAMATAN MA'RANG KABUPATEN PANGKEP
}

\author{
Marhawati $^{1}$ Muhammad Imam Ma'ruf ${ }^{2}$ \\ ${ }^{1}$ Pendidikan Ekonomi Universitas Negeri Makassar \\ Email: marhawati@unm.ac.id \\ ${ }^{2}$ Ekonomi Pembangunan Universitas Negeri Makassar \\ Email: muhammadimammaruf@unm.ac.id
}

\begin{abstract}
Abstrack. Fishery development in Province of South Sulawesi can be devided into two categories, they are marine culture and fisheries, include wild fishery and aquaculture. One of aquaculture is brackish water pond. There are several kinds of fish that can grow in brackish water pond, such as milkfish. Milkfish is a potential commodity which is not only for consume but also for export to abroad. The aim of this research is to knowing the factors which affects the production of milkfish in fishpond. The basic research which used is Explanatory Research. This research takes place in Ma'rang subdistrict Pangkep District. The population is all fisherman which total there are 804 fishermen. Simple random sampling is used to get 80 fishermen as samples. They are consist 57 fishermen in Talaka Village and 23 fishermen in Pitue Village. Primary data is gathered by doing interview with the fishermen. This research is used Cobb-Douglas function for analysis. The results of this research show variable of area of fish raising place, young milkfish, fertilizer, burden and region dummy are have significant effect toward production of milkfish in brackish water pond, while labour, feed, age and experience have no effect toeard production pf milkfish in brackish water pond.
\end{abstract}

Keywords: Cobb-Douglas function; milkfish; production.

\begin{abstract}
Abstrak. Pembangunan perikanan di Provinsi Sulawesi Selatan dapat dikelompokkan ke dalam dua kategori, yaitu perikanan laut dan perikanan darat yang di dalamnya termasuk kegiatan penangkapan dan kegiatan budidaya. Salah satu kegiatan budidaya yang dilakukan adalah budidaya tambak air payau. Di antara jenis ikan yang dapat dibudidayakan, ikan bandeng merupakan komoditas potensial yang tidak hanya dikonsumsi di dalam negeri tetapi juga diekspor ke negara lain. Tujuan penelitian ini adalah untuk mengetahui faktor-faktor yang memengaruhi produksi tambak ikan bandeng. Metode dasar yang digunakan dalam penelitian ini adalah Metode Eskplanatori. Daerah yang dijadikan tempat penelitian adalah Kecamatan Ma'rang Kabupaten Pangkep. Jumlah populasi petambak ikan bandeng adalah 804 orang. Dengan menggunakan simple random sampling, diperoleh sampel sebanyak 80 orang petambak ikan bandeng yang terdiri dari 57 orang petambak di Kelurahan Talaka dan 23 orang petambak ikan bandeng di Desa Pitue. Data primer diperoleh dengan melakukan wawancara (interview) dengan petambak ikan bandeng. Analisis data menggunakan fungsi Cobb-Douglas. Hasil penelitian menunjukkan bahwa variabel luas tambak, nener, pupuk, tanggungan keluarga dan dummy wilayah berpengaruh signifikan terhadap produksi ikan bandeng, sedangkan variabel tenaga kerja, pakan, umur dan pengalaman usaha tambak tidak berpengaruh.
\end{abstract}

Kata kunci: Ikan bandeng, fungsi cobb-douglas, produksi 


\section{PENDAHULUAN}

Proses pembangunan pada hakekatnya merupakan upaya yang dinamis, artinya pembangunan yang dilakukan oleh pemerintah melahirkan pembangunan terus menerus di berbagai bidang dengan tujuan terakhir untuk meningkatkan mutu kehidupan masyarakat. Salah satu bidang mengalami perkembangan dan perubahan dalam rangka memanfaatkan sumber daya alam dan meningkatkan mutu kehidupan sumber daya manusia adalah pembangunan di bidang perikanan.

Pembangunan perikanan di Provinsi Sulawesi Selatan dapat dikelompokkan ke dalam dua kategori, yaitu perikanan laut dan perikanan darat yang di dalamnya termasuk kegiatan penangkapan dan kegiatan budidaya. Salah satu kegiatan budidaya yang dilakukan adalah budidaya tambak air payau. Di antara jenis ikan yang dapat dibudidayakan, ikan bandeng merupakan komoditas potensial yang tidak hanya dikonsumsi di dalam negeri tetapi juga diekspor ke negara lain. Ikan ini telah dimanfaatkan untuk sumber protein hewani bagi masyarakat pesisir maupun komoditas perdagangan dengan harga yang cukup tinggi (Pranoto et al. 2017). Pemilihan budidaya ikan bandeng karena cukup digemari masyarakat Sulawesi Selatan sebagai bahan pangan yang bergizi tinggi, termasuk jenis ikan ekonomis penting karena memiliki nilai jual yang cukup tinggi, serta ikan bandeng mudah beradaptasi dan bertoleransi tinggi terhadap salinitas (0-158 ppt) tahan terhadap penyakit dan tidak bersifat kanibal (Murtidjo,1989 dalam Sadhiq, 2013).

Perkembangan sektor perikanan darat khususnya usahatani tambak, didukung oleh daerah pantai dengan rata-rata ketinggian $0,2 \mathrm{~m}$ dari permukaan laut. Pada daerah potensial tersebut, diperlukan peningkatan produksi perikanan sebagai bagian dari pembangunan ekonomi. Ikan bandeng yang merupahkan salah satu jenis ikan komoditas perikanan darat yang dibudidayakan melalui tambak, sangat perlu mendapat perhatian dalam usaha meningkatkan produksinya. Sedangkan usaha produksi ikan bandeng dapat meningkatkan pendapatan dan sekaligus taraf hidup petani tambak dari segi ekonomi. Selain itu juga dapat membuka lapangan kerja baru khususnya dalam kegiatan perdagangan jenis ikan ini. Oleh karena itu, dapat dikatakan bahwa produksi ikan bandeng memiliki andil terhadap perkembangan perekonomian sebagai bagian dari pembangunan nasional.

Sasaran dari usahatani tambak ikan bandeng pada hakekatnya memenuhi kebutuhan sehari-hari dan sebagai pendapatan pokok atau pendapatan tambahan keluarga. Dalam rangka pengembangan usahatani tambak ikan bendeng, maka berbagai langkah yang dapat ditempuh oleh para petani, baik dengan cara intensifikasi, ekstensifikasi dan sebagainnya. Semuanya itu merupakan upaya agar produksi usahatani dapat meningkat dari waktu ke waktu. Sedangkan intensifikasi dan ekstensifikasi yang meliputi perluasan tambak, penebaran nener, penggunaan pupuk yang seimbang, serta penggunan tenaga kerja yang memadai terus dilakukan agar produksi dapat lebih meningkat.

Kabupaten Pangkep sebagai kabupaten yang ada di Provinsi Sulawesi Selatan terdapat beberapa daerah tambak yang cukup berpotensi untuk dikembangkan, salah satunya adalah Kelurahan Talaka. Usaha tambak telah dikenal dan sudah berlangsung sejak lama dan telah menjadi usaha turun temurun, seperti halnya di daerah lain petani tambak di Kelurahan Talaka ini umumnya membudidayakan ikan bandeng dengan teknik pengolahan yang masih tergolong sederhana hanya mengandalkan masukan nener dan pakan sebagai bahan inputnya, berbeda dengan daerah lain yang sudah lebih maju dalam pengelolahan tambak.

Penelitian yang dilakukan oleh Sadhiq (2013) menyimpulkan bahwa secara parsial, variabel yang berpengaruh signifikan terhadap produksi ikan bandeng adalah luas lahan dan nener, sedangkan variabel yang tidak signifikan terhadap produksi ikan bandeng di Desa Gentung Kecamatan Labakkang Kabupaten Pangkep adalah tenaga kerja, pupuk, pakan, tanggungan keluarga, umur dan pengalaman usah tani.

Mengacu pada pokok permasalahan yang telah dikemukakan di atas, penelitian ini bertujuan untuk mengetahui faktor-faktor yang memengaruhi produksi ikan bandeng di Kecamatan Ma'rang Kabupaten Pangkep.

\section{METODE PENELITIAN}

Metode dasar yang digunakan dalam penelitian ini adalah metode eksplanatori. Metode eksplanatori digunakan untuk pengukuran yang cermat terhadap fenomena sosial seperti besarnya perbedaan produksi usaha tambak ikan bandeng. 
Dalam penelitian ini, populasinya merupakan keseluruhan petambak ikan bandeng di Kecamatan Ma'rang Kabupaten Pangkep, sebanyak 804 orang. Pengambilan sampel dilakukan dengan simple random sampling sebesar $20 \%$ dari jumlah populasi, yakni sebanyak 80 orang yang terdiri dari 57 orang petambak di Kelurahan Talaka dan 23 orang pertambak di Desa Pitue.

Data yang digunakan merupakan data primer yang diperoleh dengan menggunakan beberapa teknik pengumpulan data, yaitu observasi, wawancara dan dokumentasi.

Data berupa variabel terikat dan variabel bebas. Variabel terikat dalam penelitian ini adalah produksi ikan bandeng $(\mathrm{Y})$, sedangkan variabel bebasnya adalah luas tambak $\left(\mathrm{X}_{1}\right)$, nener $\left(\mathrm{X}_{2}\right)$, pupuk $\left(\mathrm{X}_{3}\right)$, pakan $\left(\mathrm{X}_{4}\right)$, tenaga kerja $\left(\mathrm{X}_{5}\right)$, umur $\left(\mathrm{X}_{6}\right)$, tanggungan keluarga $\left(\mathrm{X}_{7}\right)$, pengalaman bertambak $\left(\mathrm{X}_{8}\right)$ dan dummy perbedaan wilayah $\left(\mathrm{X}_{9}\right)$.

Untuk mengetahui pengaruh faktorfaktor produksi usaha tambak ikan bandeng terhadap peningkatan produksi, digunakan fungsi Cobb Douglas yang secara matematik dapat dituliskan sebagai berikut:

$$
\begin{aligned}
\mathrm{Y}= & \beta_{0} \mathrm{X}_{1}{ }^{\beta 1} \mathrm{X}_{2}{ }^{\beta 2} \mathrm{X}_{3}{ }^{\beta 3} \mathrm{X}_{4}{ }^{\beta 4} \mathrm{X}_{5}{ }^{\beta 5} \mathrm{X}_{6}{ }^{\beta 6} \mathrm{X}_{7}{ }^{\beta 7} \mathrm{X}_{8}{ }^{\beta 8} \\
& \mathrm{X}_{9}{ }^{\delta 1} \mathrm{e}
\end{aligned}
$$

Untuk menggunakan persamaan tersebut, dilakukan alogaritma agar persamaan menjadi linear berganda.

$$
\begin{aligned}
\mathrm{Y}= & \beta_{0}+\beta_{1} \ln \mathrm{X}_{1}+\beta_{2} \ln \mathrm{X}_{2}+\beta_{3} \ln \mathrm{X}_{3}+\beta_{4} \ln \mathrm{X}_{4}+ \\
& \beta_{5} \ln \mathrm{X}_{5}+\beta_{6} \ln \mathrm{X}_{6}+\beta_{7} \ln \mathrm{X}_{7}+\beta_{8} \ln \mathrm{X}_{8}+ \\
& \delta_{1} \mathrm{X}_{9}+\mathrm{e}
\end{aligned}
$$

Keterangan:

$$
\begin{array}{ll}
\mathrm{Y} & =\text { produksi ikan bandeng }(\mathrm{kg}) \\
\beta_{0} & =\text { konstanta } \\
\mathrm{X}_{1} & =\text { luas tambak (are) } \\
\mathrm{X}_{2} & =\text { nener (ekor) } \\
\mathrm{X}_{3}=\text { pupuk }(\mathrm{kg}) \\
\mathrm{X}_{4}=\text { pakan }(\mathrm{kg}) \\
\mathrm{X}_{5}=\text { tenaga kerja (jiwa) } \\
\mathrm{X}_{6}=\text { umur (tahun) } \\
\mathrm{X}_{7}=\text { tanggungan keluarga (jiwa) } \\
\mathrm{X}_{8}=\text { pengalaman bertambak (tahun) } \\
\beta_{1 \ldots} \ldots \text { koefisien regresi variabel } \\
\delta_{1}=\text { bebas }
\end{array}
$$

\section{Uji Asumsi Klasik \\ Uji Multikolinearitas}

Menurut Gujarati (1978) dalam Rahim (2012) mengemukakan bahwa multikolinearitas (multicollinearity) atau kolinearitas ganda merupakan kejadian yang menginformasikan terjadinya hubungan antara variabel-variabel bebas yang terdapat dalam model.

Penelitian ini menggunakan metode Variance Inflation Factor (VIF) yang terdapat pada program Statistical Program for Service Solution (SPSS). Menurut Widarjono (2005) dalam Rahim (2012), dirumuskan:

$$
\mathrm{VIF}=\frac{1}{1-\mathrm{R}^{2}{ }_{\mathrm{j}}}
$$

$\mathrm{R}^{2}{ }_{\mathrm{j}}$ diperoleh dari regresi auxiliary antara variabel bebas (dalam Rahim, 2012) atau koefisien determinasi antara variabel bebas kedengan variabel bebas lainnya (Nachrowi dan Usman, 2006 dalam Rahim 2012). Selanjutnya jika nilai VIF lebih kecil dari 10, maka tidak terdapat multikolinearitas (Widarjono, 2005 dalam Rahim, 2012).

\section{Uji Heteroskedastisitas}

Pengujian heteroskedastisitas dilakukan dengan Park Test. Menurut Park (1966) dalam Rahim (2012), bahwa varians variabel gangguan yang tidak konstan atau masalah heteroskedastisitas muncul karena residual tidak tergantung dari variabel bebas yang ada dalam model.

Keputusan ada tidaknya masalah heteroskedastisitas berdasarkan uji estimator $(\beta)$ dengan meregres $\ln \hat{e}_{i}{ }^{2}$ dengan masing-masing ln variabel bebas. Menurut Park (2007) dalam Rahim (2012), mengemukakan jika koefisien ( $\beta$ ) tidak signifikan melalui uji t, maka dapat disimpulkan tidak terdapat heteroskedastisitas atau homoscedasticity karena varians residualnya tidak tergantung dari variabel bebas, sebaliknya jika $\beta$ signifikan secara statistik maka model mengandung unsur heteroskedastisitas karena besar kecilnya varian residual ditentukan oleh variabel bebas.

\section{Uji Statistik \\ Koefisien Determinasi}

Pengukuran Ketepatan atau kesesuaian model (goodness of fit) dilakukan dihitung melalui $\mathrm{R}^{2}$ dan Adjusted $\mathrm{R}^{2}$. Pada $\mathrm{R}^{2}$ diartikan besarnya persentase sumbangan variabel bebas (X) terhadap variasi (naik-turunnya) variabel terikat (Y), sedangkan lainnya merupakan sumbangan dari faktor lainnya yang tidak masuk dalam model atau (Gujarati, 1978 dalam Rahim, 2010). Untuk mengukur proporsi (bagian) atau 
persentase total variasi dalam $\mathrm{Y}$ yang dapat dijelaskan oleh $\mathrm{X}$ dalam model regresi. Menurut Gujarati (2004) dalam Rahim (2010), dirumuskan:

$$
\mathrm{R}^{2}=\frac{\mathrm{ESS}}{\mathrm{TSS}}
$$

atau

$$
\mathrm{R}^{2}=1-\frac{\mathrm{RSS}}{\mathrm{TSS}}
$$

Keterangan:

$\mathrm{R}^{2}=$ koefisien determinasi

ESS $=$ jumlah kuadrat dapat dijelaskan (explained sum of square $)=\sum(\hat{\mathrm{Y}}-\mathrm{Y})^{2}$

$\mathrm{TSS}=$ total jumlah kuadrat (total sum of square $)=\sum(\mathrm{Y}-\mathrm{Y})^{2}$

RSS $=$ residual jumlah kuadrat tidak dapat dijelaskan (residual sum of square) $=$ $\sum(\mathrm{Y}-\hat{\mathrm{Y}})^{2}$

Nilai $\mathrm{R}^{2}$ selalu meningkat dengan bertambahnya variabel bebas dari suatu model, hal tersebut menjadi kelemahan $\mathrm{R}^{2}$. Menurut Gujarati (1978) dalam Rahim (2010), untuk mengatasi hal tersebut dipergunakan yang $\mathrm{R}^{2}$ disesuaikan (adjusted $\mathrm{R}^{2}$ ), sehingga dapat menghindari terjadinya bias terhadap variabel bebas yang dimasukkan dalam model. Menurut Gujarati (2004) dalam Rahim (2010), dirumuskan:

$$
\text { Adjusted } \mathrm{R}^{2}=1-\left(1-\mathrm{R}^{2}\right) \frac{(\mathrm{n}-1)}{(\mathrm{k}-1)}
$$

Keterangan:

Adjusted $\mathrm{R}^{2}=$ koefisien determinasi yang disesuaikan

$$
\begin{array}{ll}
\mathrm{R}^{2} & =\text { koefisien determinasi } \\
\mathrm{N} & =\text { jumlah sampel } \\
\mathrm{k} & =\text { jumlah variabel tidak termasuk } \\
& \text { intersep }
\end{array}
$$

\section{Uji F}

Pada tabel anavar dengan tujuan untuk mengetahui apakah faktor yang mempengaruhi produktivitas dan pendapatan petani, secara bersama-sama mempunyai pengaruh yang bermakna terhadap tingkat produktivitas dan pendapatan petani. Menurut Gujarati (2004) dirumuskan:

$$
\begin{array}{r}
\mathrm{F}_{\text {hitung }}=\frac{\mathrm{ESS} /(\mathrm{k}-1)}{\mathrm{RSS} /(\mathrm{n}-\mathrm{k})} \\
\mathrm{F}_{\text {tabel }}\{(\mathrm{k}-1):(\mathrm{n}-\mathrm{k}) ; \alpha\}
\end{array}
$$

Keterangan:

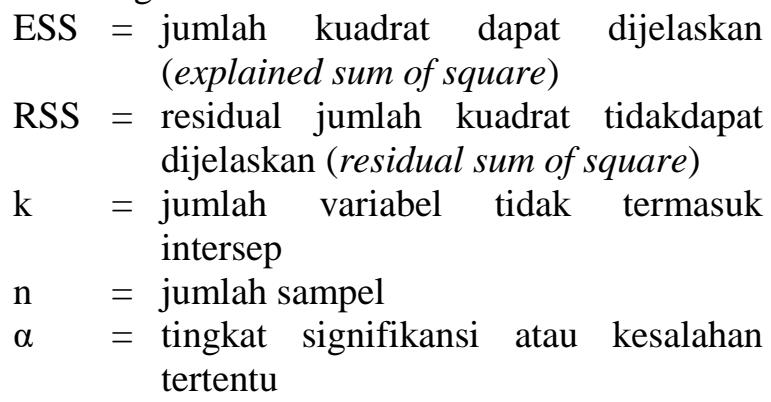

Dengan hipotesis sebagai berikut:

$\mathrm{H}_{0}=\beta_{0}+\beta_{1}+\ldots+\beta_{7}=0$ artinya tidak terdapat pengaruh variabel bebas ke- $i$ terhadap variabel terikat

$\mathrm{H}_{1}=$ sekurang-kurangnya satu nilai $\beta$ tidak sama dengan nol artinya terdapat pengaruh variabel bebas ke-i, secara bersama-sama terhadap variabel terikat

Kriteria pengujian adalah $\mathrm{H}_{0}$ ditolak dan $\mathrm{H}_{1}$ diterima, jika nila $\mathrm{F}_{\text {hitung }}>\mathrm{F}_{\text {tabel }}$ pada taraf $\alpha: 0.05$. Sebaliknya jika $F_{\text {hitung }} \leq$ dari nilai $\mathrm{F}_{\text {tabel }}$, maka $\mathrm{H}_{0}$ diterima dan menolak $\mathrm{H}_{1}$, yang berarti variabel bebas ke-i, secara bersamasama tidak berpengaruh nyata terhadap variabel terikat.

\section{Uji t}

Digunakan untuk mengetahui keberartian masing-masing faktor pengeluaran petani terhadap tingkat pendapatan petani. Menurut Gujarati (2004), dirumuskan:

$$
t_{\text {hitung }}=\frac{\beta \mathrm{i}}{\mathrm{S} \beta \mathrm{i}}
$$

$\mathrm{t}_{\text {tabel }}\{(\mathrm{n}-\mathrm{k}) ; \alpha\}$

Keterangan:

$\beta \mathrm{i}=$ koefisien regresi ke- $\mathrm{i}$

$\mathrm{S} \beta \mathrm{i}=$ kesalahan standar koefisien regresi ke-i

$\mathrm{k} \quad=$ jumlah variabel tidak termasuk intersep

$\mathrm{n} \quad=$ jumlah sampel

$\alpha=$ tingkat signifikansi atau kesalahan tertentu

Dengan Hipotesis:

$\mathrm{H}_{0}: \beta_{\mathrm{i}}=(\mathrm{i}=1, \ldots, 7)=0$

$\mathrm{H}_{1}: \beta_{\mathrm{i}} \neq 0(\mathrm{i}=1, \ldots, 7)$ 
Kriteria pengujian keputusan adalah jika $t_{\text {hitung }}>\mathrm{t}_{\text {tabel }}$, maka $\mathrm{H}_{0}$ ditolak dan menerima $\mathrm{H}_{1}$, yang berarti variabel bebas ke-i, secara parsial berpengaruh nyata (tidak signifikan) terhadap variabel terikat, sedangkan jika $t_{\text {hitung }} \leq t_{\text {tabel }}$, maka $\mathrm{H}_{0}$ diterima dan menolak $\mathrm{H}_{1}$, yang berarti variabel bebas ke-i, secara individu tidak berpengaruh nyata (signifikan) terhadap variabel terikat.

\section{Hasil Penelitian}

Hasil analisis faktor-faktor yang memengaruhi produksi ikan bandeng di Kecamatan Ma'rang Kabupaten Pangkep dapat dilihat pada tabel 1 .

Berdasarkan hasil analisis regresi maka dihasilkan persamaan regresi:

$$
\begin{aligned}
\text { LnQPIB }= & -0,301 \text { LnLLT }+0,229 \text { LnJTK + } \\
& 0,424 \text { LnNNR + 0,055 LnPKN + } \\
& 0,458 \text { LnUMR + 0,195 LnTGK + } \\
& 0,221 \text { LnPUT + 0,399 DmTLK }+\mu
\end{aligned}
$$

\begin{tabular}{|c|c|c|c|c|c|c|c|}
\hline \multirow{2}{*}{ No. } & \multirow{2}{*}{ Variabel Bebas } & \multirow{2}{*}{$\mathrm{TH}$} & \multirow{2}{*}{$\beta$} & \multirow{2}{*}{$t_{\text {hitung }}$} & \multirow{2}{*}{ Sig } & \multicolumn{2}{|c|}{ Uji Asumsi Klasik } \\
\hline & & & & & & VIF & Park Test \\
\hline 1 & Luas lahan & + & $0,251^{*}$ & 3,121 & $0.000 * * *$ & 3,614 & 0,122 \\
\hline 2 & Jumlah tenaga kerja & + & $0,229^{\mathrm{ns}}$ & 1,883 & $0,114^{\mathrm{ns}}$ & 2,138 & 0,257 \\
\hline 3 & Volume nener & + & $0,424 *$ & 5,004 & $0.000 * * *$ & 3,327 & 0,133 \\
\hline 4 & Volume pupuk & + & $0,256^{* *}$ & 2,965 & $0,085^{*}$ & 4,323 & 0,136 \\
\hline 5 & Volume pakan & + & $0,055^{\mathrm{ns}}$ & 1,191 & $0,376^{\mathrm{ns}}$ & 1,343 & 0,357 \\
\hline 6 & Umur & + & $-0,458^{\text {ns }}$ & $-2,415$ & $0,481^{\text {ns }}$ & 1,462 & 0,325 \\
\hline 7 & Tanggungan keluarga & + & $0,195 * * *$ & $-1,685$ & $0,005^{* *}$ & 1,306 & 0,402 \\
\hline 8 & Pengalaman usahatani & + & $0,221^{\mathrm{ns}}$ & 1,074 & $0,193^{\mathrm{ns}}$ & 1,096 & 0,53 \\
\hline 9 & Dummy Talaka & + & $0,399 * * *$ & 4,03 & $0.000 * * *$ & 1,344 & 0,638 \\
\hline \multicolumn{2}{|c|}{ Konstanta } & & & & & & $-0,301$ \\
\hline \multicolumn{2}{|c|}{$F_{\text {hitung }}$} & & & & & & 32,142 \\
\hline \multicolumn{8}{|c|}{$F_{\text {tabel }}$} \\
\hline \multicolumn{8}{|c|}{$t_{\text {tabel }}$} \\
\hline \multicolumn{2}{|c|}{ Adjusted $\mathrm{R}^{2}$} & & & & & & 0,78 \\
\hline \multicolumn{2}{|l|}{$\mathrm{N}$} & & & & & & 80 \\
\hline
\end{tabular}

\section{HASIL DAN PEMBAHASAN}

Tabel 1. Analisis Faktor-faktor yang Memengaruhi Produksi Ikan Bandeng di Kecamatan Ma'rang Kabupaten Pangkep Tahun 2016

Sumber: Data primer, 2016 (diolah)

Keterangan:

$\begin{array}{ll}\mathrm{TH} & =\text { Tanda harapan } \\ * * * & =\text { Taraf Signifikansi 0,01 }(1 \%) \\ * * & =\text { Taraf Signifikansi } 0,05(5 \%) \\ * & =\text { Taraf Signifikansi } 0,10(10 \%) \\ \mathrm{ns} & =\text { Tidak signifikan }\end{array}$

VIF $=$ Jika nilai VIF lebih kecil dari 10 maka tidak terdapat multikolinearitas, sebaliknya jika nilai VIF lebih besar dari 10 maka terjadi multikolinearitas

Park Test $=\quad$ Tidak signifikan; jika nilai $\beta$ tidak terdapat heterokedastisitas, sebaliknya jika nilai $\beta$ signifikan, maka terdapat heterokedastisitas 


\section{PEMBAHASAN}

\section{Uji Asumsi Klasik}

\section{Uji Multikolinearitas}

Uji Multikolineritas dengan pengukuran terhadap VIF (variance inflaction factor) menunjukkan bahwa semua variabel independen pada model yang diajukan bebas dari multikolinearitas atau tidak ada multikolinearitas antar variabel independen dalam model. Hal ini ditunjukkan dengan nilai VIF yang berada di bawah 8 , sehingga dapat dikatakan bahwa persamaan tidak mengandung multikolinearitas.

\section{Uji Heteroskedastisitas}

Pengujian heteroskedastisitas dengan menggunakan park test menghasilkan nilai koefisien ( $\beta$ ) tidak signifikan maka dapat disimpulkan tidak terdapat heteroscedasticity.

\section{Uji Statistik}

\section{Koefisien Determinasi}

Nilai adjusted $\mathrm{R}^{2}$ sebesar 0,78 berarti variansi faktor produksi, luas lahan tambak, pupuk, nener, pakan, jumlah tenaga kerja, umur, tanggungan keluarga, pengalaman usahatani, dummy Talaka memberikan kontribusi $78 \%$ terhadap produksi ikan bandeng di Kecamatan Ma'rang Kabupaten Pangkep sedangkan sisanya 23\% dipengaruhi oleh faktor yang tidak dimasukkan dalam penelitian ini.

Uji F

Uji $\mathrm{F}$ menunjukkan bahwa nilai $\mathrm{F}$ hitung sebesar 32,142 dengan signifikansi 0,01 jauh lebih kecil dari taraf signifikansi yang digunakan dalam penelitian ini yaitu 0,10 atau $10 \%$. Hal ini menunjukkan bahwa luas lahan, jumlah tenaga kerja, nener, pupuk, umur, pengalaman usahatani, dan dummy Talaka secara simultan mempunyai pengaruh yang signifikan terhadap produksi ikan bandeng di Kecamatan Ma'rang Kabupaten Pangkep.

Untuk mengetahui faktor produksi mana saja yang mempunyai pengaruh yang bermakna terhadap produksi ikan bandeng di Kecamatan Ma'rang Kabupaten Pangkep maka dilakukan Uji t.

Uji t

\section{Luas Lahan}

Variabel luas lahan berpengaruh positif terhadap produksi ikan bandeng di Kecamatan Ma'rang Kabupaten Pangkep, karena sesuai dengan tanda harapan dan nilai t hitung sebesar 3,121 dengan nilai signifikan 0,000 jauh lebih kecil dari taraf siginifikan yang digunakan yaitu 0.001 artinya luas lahan berpengaruh positif dan signifikan terhadap produksi ikan bandeng. Koefisien regresi yang bernilai 0,251 berarti setiap penambahan 1 persen luas lahan akan meningkatkan produksi ikan bandeng sebesar 0,251 persen. Hal ini karena petani tambak ikan bandeng telah mengoptimalkan dengan baik luas lahan yang ada.

\section{Jumlah Tenaga Kerja}

Jumlah tenaga kerja berpengaruh tidak signifikan karena nilai t hitung 1,883 dan diikuti nilai koefisien $\beta$ yang bernilai 0,229 dengan nilai signifikan 0,114 jauh lebih besar dari pada taraf signifikasi 0,10 yang digunakan, artinya jumlah tenaga kerja mempunyai pengaruh yang tidak signifikan terhadap produksi ikan bandeng.

\section{Nener}

Variabel nener berpengaruh positif signifikan terhadap produksi ikan bandeng, dilihat dari nilai t hitung sebesar 5,004 dengan koefisien regresi 0,424 yang diikuti oleh nilai signifikan sebesar 0,000 jauh lebih kecil dari taraf signifikan yang digunakan dalam penelitian ini yaitu 0,01 persen. Selanjutnya koefisien regresi sebesar 0,424 yang berarti setiap penambahan 1 persen nener akan meningkatkan produksi usahatani tambak ikan bandeng sebesar 0,424 persen.

\section{Pupuk}

Tambak diberi pupuk organik berupa kotoran ayam dengan jumlah 1 ton/ha. Setelah empat hari pemupukan, kemudian level air dinaikkan hingga $60 \mathrm{~cm}$ dan nener mulai ditebar. Jumlah nener yang ditebar dalam ipukan sebanyak 20.000 ekor lalu dipelihara selama 45 hari (Budi et al. 2018 ).

Volume pupuk berpengaruh positif terlihat dari nilai t hitung 2,965 dan diikuti nilai koefisien $\beta$ yang bernilai positif 0,256 dengan tingkat signifikasi 0,085 lebih kecil dari pada taraf signifikansi 0,10 yang artinya pupuk mempunyai pengaruh positif dan signifikan terhadap produksi ikan bandeng. Koefisien regresi sebesar 0,256 yang berarti bahwa setiap penggunaan pupuk 1 persen akan meningkatkan produksi ikan bandeng sebesar 0,256 persen.

\section{Pakan}

Faktor yang memengaruhi terhadap adaptasi morfologi ikan bandeng dapat berupa kualitas air dan komposisi pakan yang diberikan. Benih ikan bandeng akan tumbuh lebih baik jika kondisi kualitas air di tambak dan kualitas pakan yang diberikan memadai sehingga dapat mendukung 
pertumbuhan benih tersebut (Budi et al. 2018).

Variabel pakan terhadap usahatani tambak ikan bandeng berpengaruh positif namun tidak signifikan terhadap produksi ikan bandeng. Dilihat dari nilai t hitung 1,191 dengan koefisien regresi 0,055 yang diikuti oleh nilai signifikan sebesar 0,376 jauh lebih besar dari taraf signifikan yang digunakan dalam penelitian ini yaitu $0,10 \%$. Selanjutnya koefisien regresi sebesar 0,055 yang berarti setiap penambahan 1 persen pakan akan mengurangi produksi usaha tani tambak ikan bandeng sebesar 0,055 persen. Umur

Variabel umur berpengaruh negatif dan tidak signifikan terhadap produksi ikan bandeng karena nilai t hitung $-2,415$ dengan koefisien regresi $-0,458$ diikuti oleh nilai signifikansi sebesar 0,481 jauh lebih besar dari taraf signifikan yang digunakan dalam penelitian ini yaitu $0,10 \%$. Selanjutnya koefisien regresi sebesar $-0,458$ yang berarti setiap penambahan 1 tahun umur akan mengurangi produksi usaha tani tambak ikan bandeng sebesar 0,458 persen.

\section{Tanggungan Keluarga}

Tanggungan Keluarga secara tidak langsung, berpengaruh positif terhadap produksi ikan bandeng di Kecamatan Ma'rang Kabupaten Pangkep dengan koefisien regresi variabel tanggungan keluarga $-1,685$ yang diikuti oleh nilai signifikan sebesar 0,005 jauh lebih kecil dari taraf signifikan yang digunakan dalam penelitian ini yaitu $0,05 \%$. Selanjutnya koefisien regresi sebesar 0,195 yang berarti setiap penambahan 1 orang tanggungan keluarga usahatani tambak akan meningkatkan produksi usahatani ikan bandeng sebesar 0,195 persen.

\section{Pengalaman Usahatani}

Pengalaman usahatani tidak berpengaruh signifikan terhadap produksi ikan bandeng di Kecamatan Ma'rang Kabupaten Pangkep, hal ini dilihat dari koefisien regresi variabel pengalaman usahatani 0,221 yang diikuti oleh nilai signifikan sebesar 0,193 jauh lebih besar dari taraf signifikan yang digunakan dalam penelitian ini yaitu $0,10 \%$. Selanjutnya koefisien regresi sebesar 0,221 yang berarti setiap penambahan 1 tahun pengalaman usahatani tambak akan menurunkan produksi usahatani tambak ikan bandeng sebesar 0,221 persen.

\section{Dummy Talaka}

Dummy Talaka berpengaruh positif untuk signifikan terhadap produksi ikan bandeng di Kecamatan Ma'rang Kabupaten Pangkep. Nilai koefisien regresi variabel dummy Talaka sebesar
0,399 diikuti oleh nilai signifikansi 0.000 , jauh lebih kecil dari taraf signifikansi sebesar $0,01 \%$. Hal ini telah sesuai dengan tanda harapan, yaitu dapat diartikan produksi ikan bandeng di Kelurahan Talaka lebih besar dibandingkan dengan Desa Pitue. Hal ini terbukti secara aktual bahwa produksi ikan bandeng Kelurahan Talaka sebesar $66.974 \mathrm{~kg}$ lebih besar dari Desa Pitue.

Berdasarkan hasil penelitian terdapat lima variabel yang berpengaruh signifikan terhadap produksi ikan bandeng yaitu: luas lahan, nener, pupuk, jumlah tanggungan keluarga dan dummy Talaka, sedangkan variabel jumlah tenaga kerja, pakan, umur dan pengalaman usahatani tidak berpengaruh signifikan terhadap produksi ikan bandeng.

\section{SIMPULAN DAN SARAN}

Faktor produksi luas tambak, tenaga kerja, nener, pupuk, pakan, tanggungan keluarga, umur dan pengalaman bertambak, serta perbedaan wilayah berpengaruh secara simultan (bersamasama) terhadap produksi ikan bandeng di Kecamatan Ma'rang Kabupaten Pangkep. Secara parsial, variabel yang berpengaruh signifikan terhadap produksi ikan bandeng di Kecamatan Ma'rang Kabupaten Pangkep adalah luas tambak, nener, pupuk, tanggungan keluarga, dan perbedaan wilayah, sedangkan variabel yang tidak berpengaruh adalah tenaga kerja, pakan, umur dan pengalaman bertambak.

Agar produksi ikan bandeng dapat meningkat secara optimal, diharapkan pemerintah setempat, khususnya Dinas Perikanan, meningkatkan pembinaan dan penyuluhan kepada para petambak ikan bandeng khususnya dalam penggunaan pupuk dan pakan.

\section{DAFTAR RUJUKAN}

Budi, S., Sembiring, M., Wibawa, G. S., \& Setiadharma, T. (2018). Pertumbuhan dan Variasi Genetik Ikan Bandeng, Chanos chanos dari Provinsi Aceh, Bali, dan Gorontalo, Indonesia, 12(4), 307314.

Djumanto, Pranoto, B. E., Diani, V. S., \& Setyobudi, E. (2017). Makanan dan Pertumbuhan Ikan Bandeng, Chanos chanos (Forsskål, 1775) tebaran di Waduk Sermo, Kulon Progo. Jurnal Iktiologi Indonesia, 17(1), 83-100.

Sadhiq, Muhammad. 2013. Analisis Faktorfaktor yang Mempengaruhi Produksi Tambak Ikan Bandeng di Desa Gentung Kecamatan Labakkang Kabupaten 
Pangkajene Kepulauan [skripsi]. Makassar: Universitas Negeri Makassar. Rahim, Abd. 2010. Analisis Harga Ikan Laut Segar dan Pendapatan Usaha Tangkap Nelayan di Sulawesi Selatan [disertasi].
Yogjakarta: Program Pasacasarjana Universitas Gadjah Mada. 2012. Model Analisis Ekonomika Pertanian. Makassar: Badan Penerbit UNM. 